\title{
13. SITE 457: MARIANA ISLAND ARC ${ }^{1}$
}

\author{
Shipboard Scientific Party²
}

\section{SITE 457}

\begin{abstract}
Date occupied: 16 April 1978
\end{abstract}
Date departed: 17 April 1978

Time on hole: 25 hours, 30 minutes

Position: $17^{\circ} 49.99^{\prime} \mathrm{N}$; $145^{\circ} 49.02^{\prime} \mathrm{E}$

Water depth (sea level; corrected m, echo-sounding): 2630

Water depth (rig floor; corrected m, echo-sounding): 2640

Bottom felt (m, drill pipe): 2647

Penetration $(\mathrm{m})^{3}: 61.0$

Number of holes: 1

Number of cores ${ }^{3}: 6$

Total length of cored section $(\mathrm{m}): 51.5$

Total core recovered $(\mathrm{m}): 19.42$

Core recovery $(\%): 37.5$

Oldest sediment cored:

Depth sub-bottom $(\mathrm{m}): 51.5$

Nature: coarse sand

Age: late Pleistocene

\section{Basement:}

Depth sub-bottom (m): Not attained

Principal results: Site 457 was located on the axis of the Mariana Island Arc, near the northeastern base of Alamagan Island, where very thick, apparently volcaniclastic sediments pinch out. The objective of Site 457 was to determine the structure and nature of the arc upon which the present volcanoes are built. This would permit direct comparison with the Palau-Kyushu and West Mariana Ridges drilled on Leg 59. Unfortunately, we were able to penetrate only 51.5 meters with 37.5 per cent recovery.

The cores were coarse sand and drilling breccia, derived from volcanic rock, pumice, and ash. They are all late Pleistocene in age (nannofossils in oldest sediment: Emiliania ovata Subzone).

\section{BACKGROUND AND OBJECTIVES}

For comparison with sites drilled during Leg 59 on the Palau-Kyushu Ridge (Site 448) and the West Mari-

\footnotetext{
1 Initial Reports of the Deep Sea Drilling Project, Volume 60.

2 Donald M. Hussong (co-chief scientist), Hawaii Institute of Geophysics, Honolulu, Hawaii; Seiya Uyeda (co-chief scientist), Earthquake Research Institute, University of Tokyo, Tokyo, Japan; René Blanchet, Université de Bretagne Occidentale, Brest, France; Ulrich Bleil, Institut für Geophysik, Ruhr Universität, Bochum, Federal Republic of Germany; C. Howard Ellis, Marathon Oil Company, Denver Research Center, Littleton, Colorado; Timothy J. G. Francis, Institute of Oceanographic Sciences, Surrey, United Kingdom; Patricia Fryer, Hawaii Institute of Geophysics, Honolulu, Hawaii: Ki-lti Horai, Lamont Doherty Geological Observatory, Palisades, New York; Stanley Kling, Marine Life Research Group, Scripps Institution of Oceanography, La Jolla, California (present address: 416 Shore View Lane, Leucadia, California); Arend Meijer, Department of Geosciences, University of Arizona, Tueson, Arizona; Kazuaki Nakamura, Earthquake Research Institute, University of Tokyo, Tokyo, Japan; James H. Natland, Deep Sea Drilling Project, Scripps Institution of Oceanography, La Jolla, California; Gordon H. Packham, Department of Geology and Geophysics, University of Sydney, Sydney, N.S.W. Australia; and Anatoly Sharaskin, Vernadsky Institute of Geochemistry, U.S.S.R. Academy of Sciences, Moscow, U.S.S.R

${ }^{3}$ Six cores were recovered from 51.5 meters of penetration. A seventh core, from 51.5 to 61.0 meters sub-bottom, was attempted but was not recorded on logs because it (1) did not penetrate to the planned depth due to infilling of the hole and (2) was empty when brought aboard.
}

ana Ridge (Site 451), a site was planned for Leg 60 in survey area SP-3B, on the axis of the active volcanic Mariana Arc in the saddle between Pagan and Alamagan Islands (Fig. 1). The principal objectives of this site were:

1) to penetrate the underlying arc upon which the volcanoes are built, in order to date and characterize the ridge and be able to compare it with similarly placed holes in other arcuate ridges; and

2) to penetrate the young lavas which form the upper portions of the Mariana Ridge to see if these Ridge lavas are of different compositions than the eruptive rocks of the islands.

Admittedly, these objectives were optimistic in that they required deep penetration in an area where thick layers of sand and flows were expected. Furthermore, the site was included in the Leg 60 program by the South Philippine Sea Working Group after the completion of IPOD site selection survey work in the Mariana region, so less background knowledge of this target area was available than was the case for our other sites. After profiling several hours, a site was selected near the northeastern base of Alamagan Island (about $24 \mathrm{~km}$ from the island), where the Glomar Challenger air-gun records showed pinching out of the very thick sediments between Pagan and Alamagan Islands (Fig. 2). If basement rocks could be reached at the base of Alamagan, they might be (1) older arc material, or (2) particularly large or less viscous (tholeiitic?) flows from earlier stages of volcanism on Alamagan that traveled far from the center of eruption, or (3) with sufficient penetration, volcanic arc lavas beneath the Alamagan pedestal that

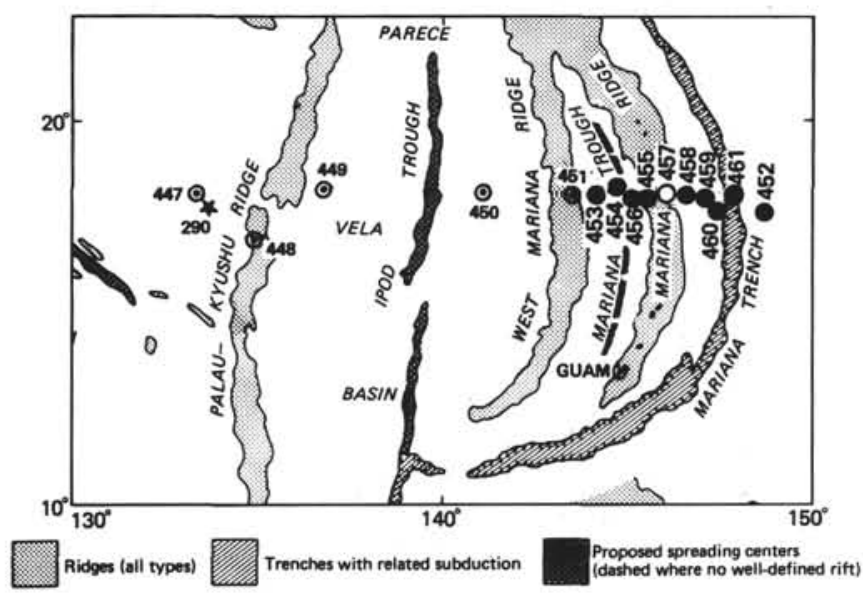

Figure 1. Location map of Site 457 (open circle) and other Leg 60 sites (solid circles). 


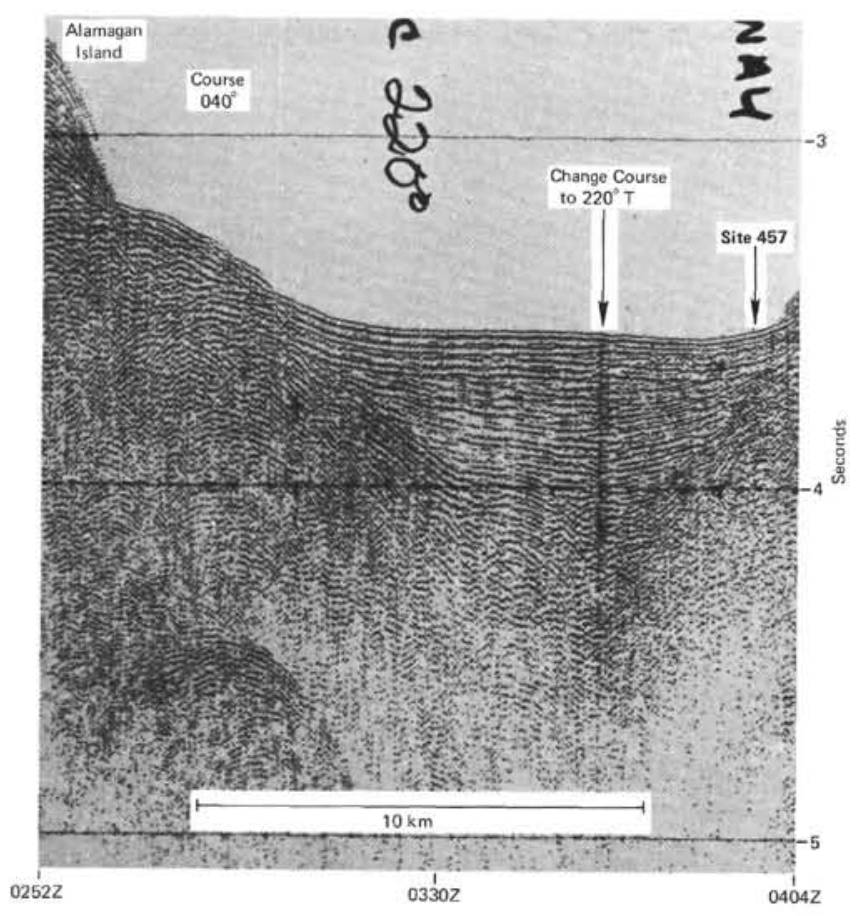

Figure 2. Single-channel reflection seismic profile, Site 457. A 120-cu. in. air-gun was used as a sound source.

erupted away from the islands or before the islands formed.

Neither the site survey data nor a short pre-drilling survey conducted by the Challenger found any small basement high in the saddle area that would have provided a more attractive target than the lower slope of Alamagan Island.

\section{OPERATIONS}

Site 457 was not part of the initial drilling plans for Leg 60 , so little site survey work had been done in the immediate target area. The Challenger devoted several hours to surveying the area before dropping a $13.5-\mathrm{kHz}$ double-life beacon on the site at 1400 local time, 16 April 1978.

The profiling near the site, which was done with the $12-\mathrm{kHz}$ and $3.5-\mathrm{kHz}$ bathymetry system, the $120-\mathrm{cu}$. in. air-gun and single-channel reflection seismic system, and the towed magnetometer, showed that the ridge axis saddle area between Pagan and Alamagan Islands was an essentially featureless sediment apron. Based on the experience of drilling only sand at Site 455, we sought to minimize the sediment thickness for Site 457 , where sands were also anticipated. The site that was chosen had about 200 meters of sediment (Fig. 2).

A standard bottom-hole assembly $(121.05 \mathrm{~m}$ total length) was rigged with a F93CK bit. PDR depth was 2630 corrected meters. The bit reached bottom $(2637 \mathrm{~m})$ at 0030 on 17 April.

The coring summary is listed in Table 1 and the coring rates for each core are shown in Figure 3.

The first core and all subsequent cores were full of coarse volcanic sand and the hole was unstable from the beginning of coring. In the vain hope that something
Table 1. Coring summary, Site 457.

\begin{tabular}{cccccccc}
\hline Core & $\begin{array}{c}\text { Date } \\
(\text { April } \\
1978)\end{array}$ & Time & $\begin{array}{c}\text { Depth from } \\
\text { Drill Floor } \\
(\mathrm{m})\end{array}$ & $\begin{array}{c}\text { Depth below } \\
\text { Sea Floor } \\
(\mathrm{m})\end{array}$ & $\begin{array}{c}\text { Length } \\
\text { Cored } \\
(\mathrm{m})\end{array}$ & $\begin{array}{c}\text { Length } \\
\text { Recovered } \\
(\mathrm{m})\end{array}$ & $\begin{array}{c}\text { Recovered } \\
(\%)\end{array}$ \\
\hline 1 & 17 & 0413 & $2647.0-2651.0$ & $0.0-4.0$ & 4.0 & 0 & 0 \\
2 & 17 & 0527 & $2651.0-2660.5$ & $4.0-13.5$ & 9.5 & 3.75 & 39.4 \\
3 & 17 & 0635 & $2660.5-2670.0$ & $13.5-23.0$ & 9.5 & 6.04 & 63.6 \\
4 & 17 & 0740 & $2670.0-2679.5$ & $23.0-32.5$ & 9.5 & 3.98 & 41.9 \\
5 & 17 & 0847 & $2679.5-2689.0$ & $32.5-42.0$ & 9.5 & 1.05 & 11.1 \\
6 & 17 & 0945 & $2689.0-2698.5$ & $42.0-51.5$ & $\underline{9.5}$ & $\underline{4.60}$ & $\frac{48.4}{37.5}$ \\
Total & & & & & 51.5 & 19.42 & \\
\hline
\end{tabular}

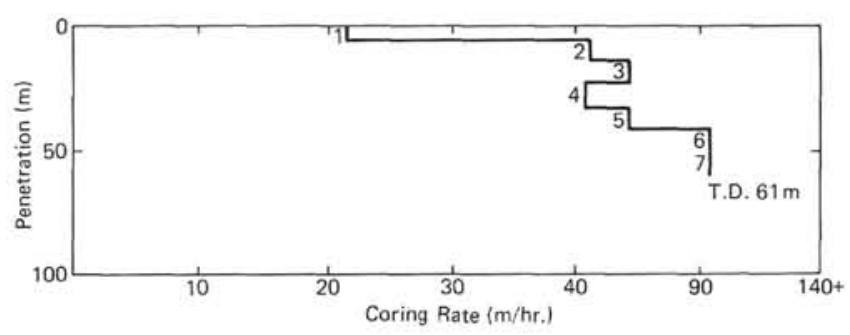

Figure 3. Coring rates for each core, Site 457, in meters per hour. T.D. = total depth. Core numbers are shown on the figure.

would change, coring was continued until torquing and sticking began during Core 7 (which returned with zero recovery), after which the hole was abandoned.

After the drill string was brought aboard and secured, we departed from Site 457 at 1551 local time on 17 April.

\section{LITHOLOGY OF SEDIMENTS}

At Site 457, 51.5 meters of sediment was penetrated (Fig. 4). Only dark gray drilling breccias and very coarse volcanic sands were recovered. They consist of light and dark volcanic rock fragments with small brownish patches of mud and about 1 per cent of carbonate fragments.

The lighter colored fragments are well-vesiculated yellowish gray to light olive-gray pumice. They are gen-

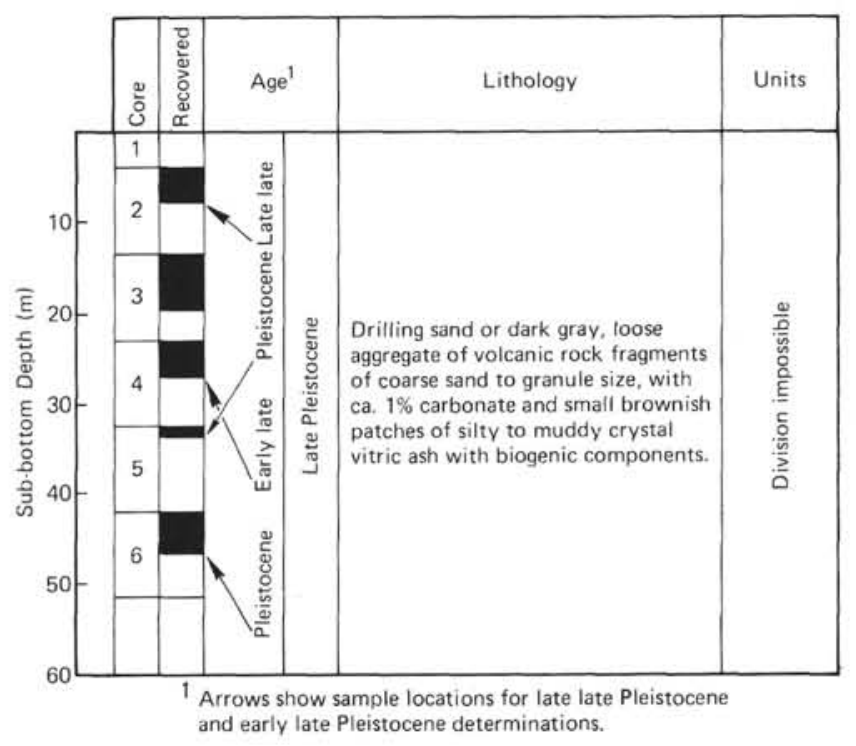

Figure 4. Lithologic column and summary lithology, Site 457. 
erally larger (up to $1.5 \mathrm{~cm}$ in diameter) and comprise up to 20 per cent of the sand volume. The dark colored fragments (olive-gray to dark gray) are glassy vesicular to non-vesicular lithic volcanic rocks. A small number of fragments are distinct in their color (e.g., moderate red and moderately yellowish green).

The brownish patches are silty to muddy crystal vitric ash with biogenic components (foraminifers, calcareous nannofossils) and unspecified carbonate. Volcanic glass in the ash is colorless or brownish, some deeply altered. Feldspars in the ash are also altered to various degrees. These features of the ashes suggest that they may be epiclastic grains rather than being directly related to specific volcanic eruptions.

Compared with similar drilling breccias recovered at Site 455 , those of Site 457 contain a wider variety of constituent fragments. In particular, the non-vesicular dark gray lithic volcanic rocks and moderate red scoria grains are characteristic and suggestive of a subaerial volcanic origin. Since Site 457 is located on the axis of the Mariana arc and is on the base of Alamagan, about $24 \mathrm{~km}$ from the active volcano on that island, it is no surprise to recover coarse sands with subaerial volcanic components.

The cored coarse volcanic ash and fine lapilli appear to alternate with soft muddy vitric ash at Site 457 . Paleontological data indicate that these layers also alternate in age between two subzones in the late Pleistocene.

\section{PALEONTOLOGY}

\section{Summary}

Core samples of coarse sand recovered at Site 457 contain sparse calcareous nannofossils, radiolarians, and foraminifers. The nature of the samples leaves considerable doubt as to the reliability of any age determination that might be made.

\section{Nannofossils}

Four core-catcher samples, which were recovered from Hole 457 before its abandonment due to caving sand, were examined for calcareous nannofossils. Although all of the samples $(2, \mathrm{CC}, 4, \mathrm{CC}, 5, \mathrm{CC}, 6, \mathrm{CC})$ consist of coarse unconsolidated sand, the fine fraction washed from them provided residues containing nannofossils. The assemblages seen in Samples 2, CC and 5,CC belong to the late Pleistocene Crenalithus cristatus Subzone of the Gephyrocapsa oceanica Zone. Samples 4,CC and 6,CC can be assigned to the Emiliania ovata Subzone of the $G$. oceanica Zone. If the recovered assemblages are indigenous to the samples, then the alternation of occurrences reflects a repetition of sampled intervals due to caving.

\section{Radiolarians}

A few specimens were recovered from the sparse, sand-size fraction of Cores 2 and 3 (CC). No zone-diagnostic species are among them.

\section{Other Microfossils}

Planktonic foraminifers are common in Cores 2 and 3 (CC), but are rare in Cores 4 through $6(\mathrm{CC})$.

\section{ACCUMULATION RATES}

Nannofossils recovered from the core-catcher samples, which consist of coarse unconsolidated sands, alternately provided two ages (subzones) of the late Pleistocene Gephyrocapsa oceanica Zone.

Very inadequate control of both ages and bedthickness data leads to estimates only of a minimum accumulation rate of 51.5 meters (total length of the cored interval) $/ 0.9$ (oldest age of $G$. oceanica Zone) $=57$. meters/m.y. for the entire late Pleistocene and a maximum rate of $35^{*} / 0.3-117$ meters $/ \mathrm{m}$.y. for the late late Pleistocene.

\section{IGNEOUS AND METAMORPHIC ROCKS}

Thin sections were made from four pebbles plucked from different cores. Two are sandstones consisting of angular fragments of fresh brown glass, rare lithic basalt grains, and abundant broken crystals, chiefly plagioclase. Two others are crystal-vitric tuffs, probably of dacite composition. They consist primarily of rounded or angular, uniformly clear glass grains containing minor plagioclase, clinopyroxene, and amphibole phenocrysts, all euhedral. Faint bedding occurs in one sample. The plagioclase has skeletal habit, and is grouped into glomerocrysts. The glass is clear, with fine needlelike plagioclase which can be seen only under crossed nicols.

\section{SUMMARY AND CONCLUSIONS}

A penetration of only 51.5 meters, with a total recovery of 19.5 meters $(37.5 \%)$, was attained at this site. The recovered cores were all coarse sand and dark gray drilling breccias of light and dark volcanic rock fragments with small patches of brownish mudstones. The light-colored fragments are vesiculated pumice, comprising up to 20 per cent of the sand volume. The dark-colored fragments are mainly glassy vesicular to non-vesicular lithic volcanic rocks. The brownish patches are silty-to-muddy crystal vitric ashes, with biogenic components. Thin sections of four pebbles indicate that they are volcaniclastic sandstones and silicic tuffs.

The ages of the nannofossils found in Core 6 can be referred to the late Pleistocene Emiliania ovata Subzone (0.3-0.9 m.y.). The limited stratigraphic sequence inferred from the cores is still suspect, because the bottom of the hole was constantly infilling with material from higher in the hole. Eventually the hole completely caved in at Core 7, which had no recovery.

Obviously, the major objectives of the site were not attained.

\footnotetext{
Sub-bottom depth of the bottom of Core 3, beneath which fossils indicating early late Pleistocene first appeared.
} 

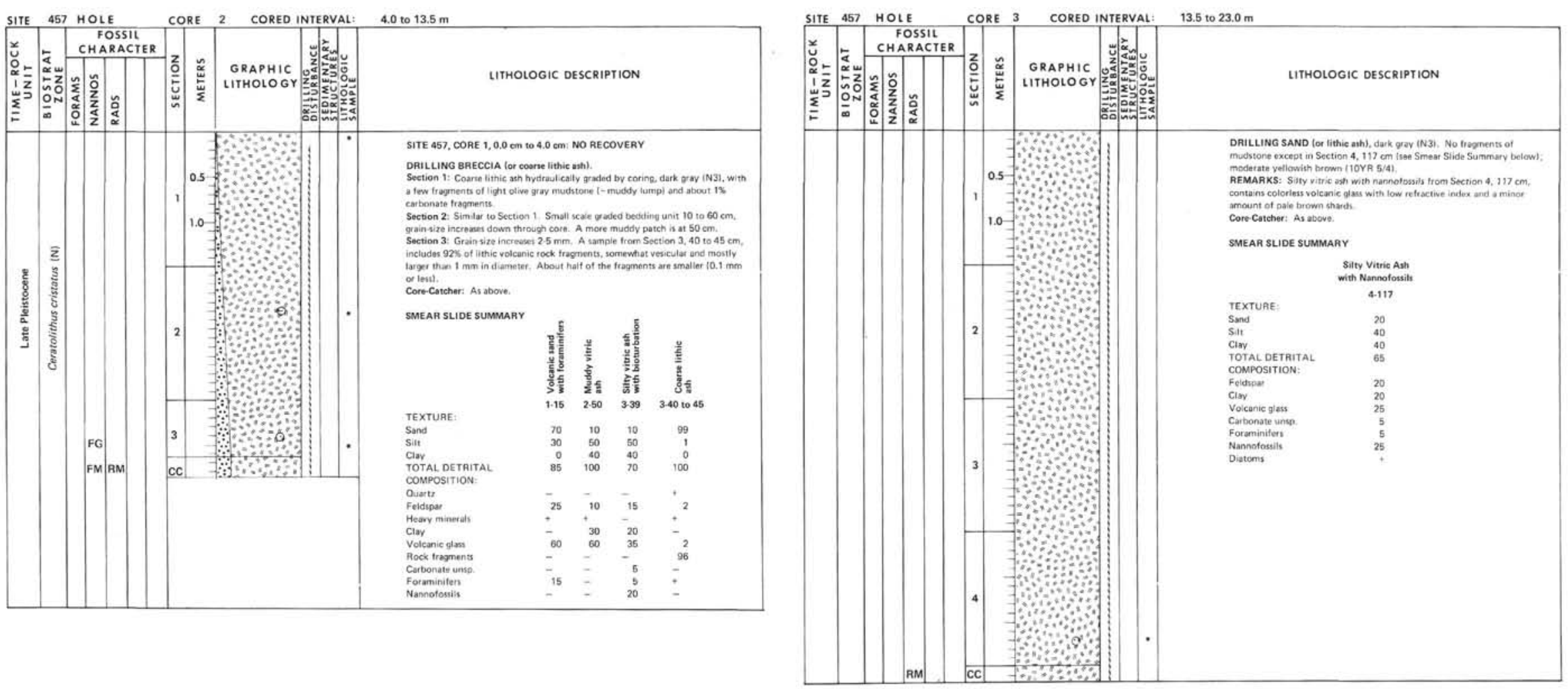

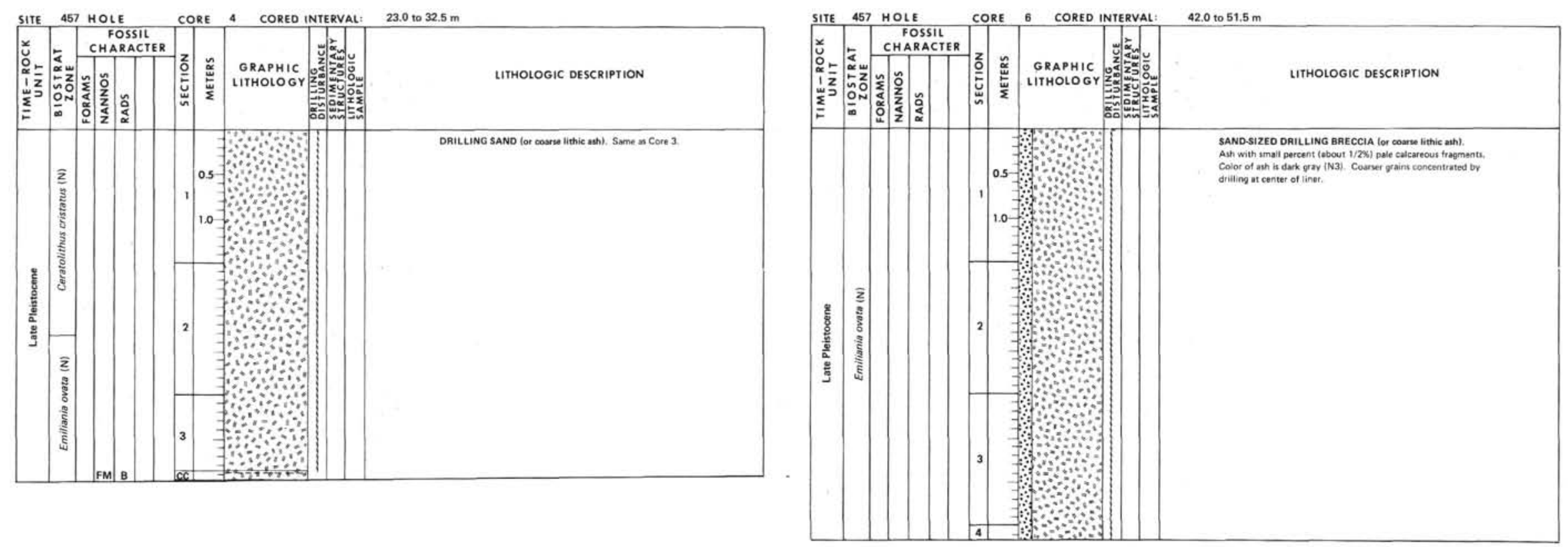

\begin{tabular}{|c|c|c|c|c|c|c|c|}
\hline IE & 457 & HOLE & $E$ & $\mathrm{cos}$ & PRE & 5 CORED INTERVAL: & 32.5 to $42.0 \mathrm{~m}$ \\
\hline & & $\begin{array}{r}\text { FO } \\
\text { CHAR }\end{array}$ & $\begin{array}{l}\text { DSSIL } \\
\text { RACIER }\end{array}$ & & & & \\
\hline 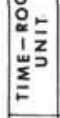 & 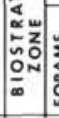 & 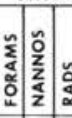 & & 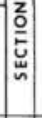 & 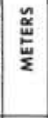 & 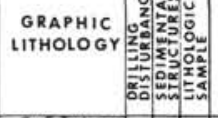 & LITHOIOGIC DESCRIPTION \\
\hline 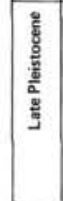 & 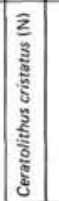 & cG & & 1 & 0.5 & $\begin{array}{l} \\
9 \\
9\end{array}$ & 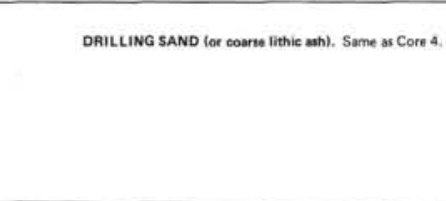 \\
\hline
\end{tabular}




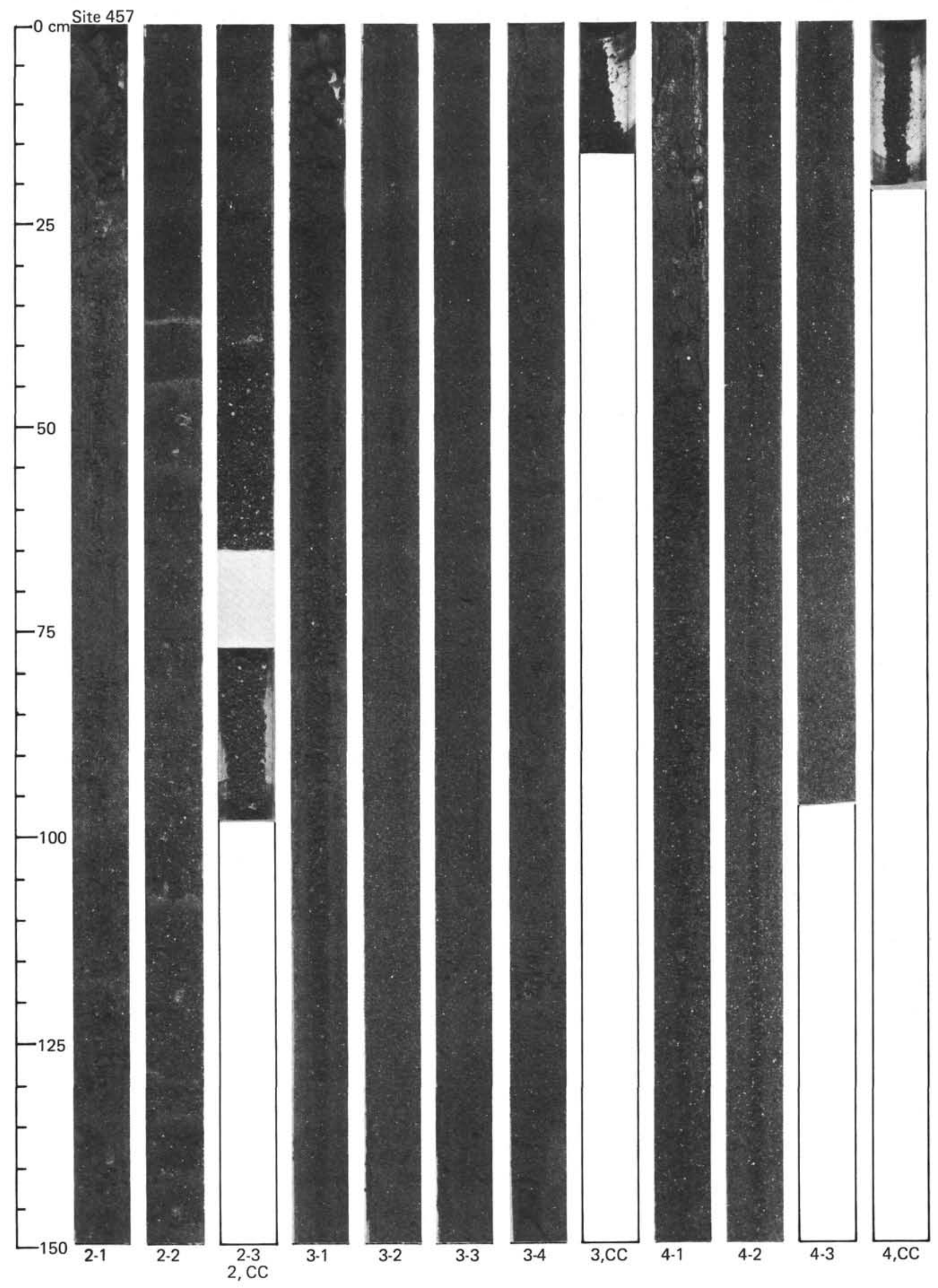




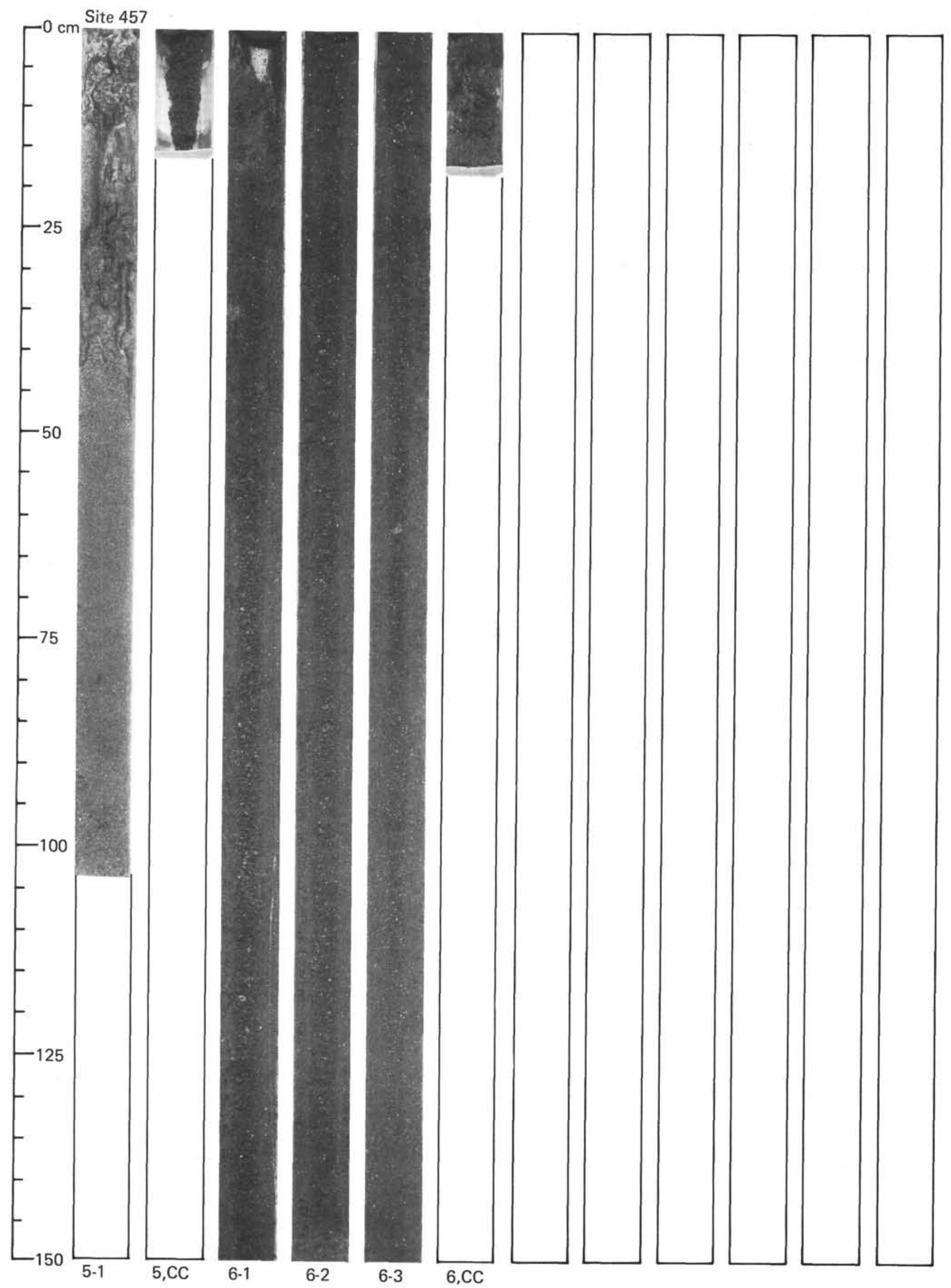

